\title{
International experience of state support and encouragement of digital economy processes ${ }^{a}$
}

\author{
Elena Pesotskaya ${ }^{2}$, and Ivan Petrov ${ }^{1 *}$ \\ ${ }^{1}$ Saint Petersburg State University of Architecture and Civil Engineering, 190005 2-ya \\ Krasnoarmeiskaya st. 4, Russian Federation \\ ${ }^{2}$ Saint Petersburg State University of Economics, 191023 Sadovaya st. 21, Russian Federation
}

\begin{abstract}
The World Economic Forum estimates that digital transformations have a huge potential for developing business and society within the next decade and the global economy can earn over $30 \operatorname{trln} \$$ additionally for a period up to 2025 [1]. A significant portion of the advantages will be given to the countries, which will deeply and comprehensively implement information and communication technologies to allow the state, society and business to interact. A high speed of data transmission and exchange of information allows innovations to diffuse both at the intra-industry and cross-industry levels, which promotes competitive strength of companies, countries and world's regions by increasing labor efficiency. In this article we have considered the programs being implemented in developed and developing countries to promote conditions for digital transformation of society and industry, boost industrial cooperation in the research and development, innovative and production areas, develop industrial and innovative infrastructure facilities, upgrade existing production facilities and create new innovative sectors of economy.
\end{abstract}

\section{Introduction}

"Digital economy" is a certain economic order, which naturally involves active use of advanced information technologies to collect, store, process, transform and transfer data in all areas of human activity. It is also a system of technical, organizational, program, normative and legislative elements with distributed interaction and mutual use by economic agents to exchange knowledge in permanent development conditions.

A wide application of digital technologies in the economy today is a reality and necessity to support competitive strength and meet consumer demands. Many states elaborate special programs at the national level due to their high efficiency. The tasks of these programs are as follows:

- Building and stable development of society, state and business;

- Improvements to support innovations being implemented at a system level;

\footnotetext{
${ }^{\mathrm{a}}$ The article was prepared as part of the work on the grant of the President of the Russian Federation NSh-4028.2018.6

*Corresponding author: petrovrf@mail.ru
} 
- Further development and binding of legislative environment to support the set-up of a "digital government";

- Arrangement of cross-border, legally relevant digital document management;

- Rendering of services in electronic format;

- Intellectual property protection;

- Information security;

- Electronic trade development;

- Development of electronic and distance learning technologies and other areas.

At the present time state programs and strategies for digital economy development have been elaborated and being implemented in different countries of the world as well as at the interstate level. So, only EU countries according to official data of the European Commission as of March 2017 there are over 30 national and regional initiatives for industrial digitization [2].

Let us consider the main provisions and peculiarities of digitization programs in developed and developing countries.

\section{Programs of EU countries}

One of the leading players in digitization and a key architect of "Industry 4.0" concept is Germany that already in 2011 officially introduced a state strategy under the same name. This program is based on the internet of things and industrial Internet of things inclusive (industrial Internet) [3]. "Industrie 4.0" was initiated by Germany's scientific and business society in 2011 and being implemented with the assistance of German chancellor Angela Merkel. By 2030 Germany's plan is to move forward to a completely different level of production, where the Internet is used to achieve maximum productivity and efficiency in industry. Apart from general concept Industry 4.0 several other strategies and initiatives of similar type have been developed and being implemented in Germany at the state level including Smart Networking Strategy [4], which formed a basis for introducing Digital Agenda program.

In July 2015, Alliance pourl' Industrie du Futur [5] was established in France to combine different organizations from private business, research society and a number of state institutes and establishments.

A new digital strategy (UK Digital Strategy 2017) was published officially relatively recently, March 1, 2017 [6].

Ambitious program Smart Industry [7] was adopted by the Government of the Netherlands. The Netherlands is one of the world's most "digitized" countries being highly rated by different global ratings for in the sphere of digital technologies. So it is number 4 in DESI rating (Digital Economy and Society Index) 2017 and is among the global leaders in terms of Internet penetration among population (number 2 worldwide in MGI rating Connectedness Index) and digitization of state services [8].

The Government of the Netherland in its general industrial policy lays emphasis on four areas:

- Strengthening of national economy's competitive power at a global level;

- Further growth of productivity in industrial sectors;

- Sustaining and increase in employment rates in industry and service sector;

- Overall improvement of business climate in the country and involvement of foreign high technology companies.

An important element of the Netherlands's industrial policy today is Smart Industry Action Agenda. A preliminary plan to launch this new strategy was first announced by the country's government in April 2014. In January 2015 this strategy was officially approved 
at the highest level. The general task tabled in this strategy is "to allow the national economy to achieve leading positions in the world by means of quick and efficient use of Information technologies in combination with advanced industrial technologies" [7].

In this case the most important objective of Smart Industry Action Agenda is to set up effective ecosystems (smart ecosystem) - interlinked networks of private companies and research and education institutions. The key practical objective of this Smart Industry program (at least at its initial stage) was a strategy to set up a wide network so called FieldLabs (field laboratories) in the country. According to the architects of this concept, FieldLabs are different physical objects within the industrial and process infrastructure, where private companies and state research organizations jointly carry out experimental developments, testing and commercially implement efficient solutions and products of "smart industry". In this case, an emphasis is laid on an interdisciplinary approach, FieldLabs should promote more efficient interaction of high-tech companies and research organization from very different industrial branches, service sector and agriculture (it should be noted that the agricultural sector is considered to be one of the most technology intensive in the Netherlands's economy). One more essential element of this strategy is to apply a bottom-up approach, when the main initiative comes from the bottom level while setting up new experimental FieldLabs (representative of private business and regional authorities of the Netherlands) [10].

As reflected in TNO's latest report (a research company being one of organizationscoordinators of the overall big project Smart Industry), the program of setting up a network of new "field laboratories" has caught the most interest of regional authorities, which view it as an effective mechanism of strengthening "smart specialization" and clustering of their territories [11]. According to the latest information posted on the official web site of Smart Industry program at the present time in the Netherlands there are already 32 these "field laboratories" being at different stages of establishment and practical operation [12].

Over the last decade European countries have been also taking certain efforts to develop "common digital agenda" in other words, joint effective solutions and control mechanisms for digitization process at the interstate level. EU leaders have defined a general long-term task to create a digital single market in Europe. For the first time the need to work out such a common strategy was officially called for by Chairman of the European Commission Jean-Claude Junker in October 2015 [13].

In 2010, EU countries launched special initiative Digital Europe as part of the implementation of more common strategy Europe 2020, the main objective of which was to stimulate the growth of common European internet economy. In the same year of 2010 so called Digital Agenda of Europe was published, it called for the development of common approaches and priorities for EU member states concerning further development of digital sectors of European economy and stimulation measures for digital innovations. In April 2016 the European commission made public a new integrated initiative under a temporary name "Digital single market- digitizing European industry, which contained a wide range of new tools and mechanism to support further digitalization of European industry and service sector [14].

\section{Programs of Asia-Pacific countries}

Countries in this region have been rationally supporting a wide use of new technologies in all economic sectors; therefore digital technologies are of no exception. In Japan the main governmental document defining the country's long-term objectives and tasks in the sphere of digital technologies is SmartJapan ICT Strategy [15], officially published in June 2014. The concept consists of two parts: National and international. Its purpose is to ensure Japan's economic growth and significant contribution to the international society and 
economy through innovations and information and communication technologies.

Special attention should be drawn to China's development of its digital society and economy. Prerequisites to this program were developed at the start of the century and in 2007 China's State Council put forward a first draft system, whose tasks were to collect data on bank clients and determine their creditworthiness in accordance with available information, payment and credit history $[14,17]$. It is worth noting that as of today these systems are already in place in many developed European countries and USA [18].

The full-scale SCS system has been designed since 2014. The program should start in 2020 according to the plan. It should be noted that up to now the government keeps the SCS system design details in secret. It is only known that the population rating will be individual for every citizen and will be identified in accordance with ID card, it is also known that certain measures will be taken in case of refusal to use this system.

In 2018, it is planned to start an experimental version of this "credit-social system" for several cities in China. It is planned to assign an initial base rating equal to 1000 points to citizens and monitor its dynamics: a model citizen will be that person whose rating will be growing. In accordance with its growth he or she will be getting certain preferences in the form of preferential credit interest, travel privilege, medical service etc. At the same time, certain sanction measures will be introduced for citizens, whose rating will be decreasing [18].

Moreover, the rating will be assigned not only to individuals but to legal entities as well. Thus, companies will be motivated to timely submit financial statements, without notice pass all audits and inspections in exchange for favorable business conditions [19].

After this reform was presented to society, the state has made a decision to set the SCS system with 10 companies including such giants as Alibaba and Tencent. Two world's largest internet companies have launched similar applications for gadgets, which after receipt of registered user's permission can receive all available information about him or her. Tencent mainly uses messenger programs to send short messages. They have managed to collect over billion users [20]! Internet-giant Alibaba through its corporate application Alipay gets information about users' transactions, paid purchases etc. It involves over half a million users [17]. In addition, the both applications receive information about people's activities from municipalities, police stations, research centers and private companies. A user's rating is built according to this database: The higher it is the more bonuses a person gets.

State authorities in the sphere of law enforcement also benefit from these programs. For example, Sesame Credit helps the PRC's High court in its search of suspects and criminals by providing all available data on some people in the public interest. According to 2015 statistics it helped detain around 6000 people later made accountable for criminal, civil and administrative actions [18].

South Korea does not lag behind in digitizing its economy either. The main current state documents in the sphere of South Korea's research and manufacturing policy is the Third Basis Plan for the development of science and technologies that was implemented in a period from 2013 to 2017 . It separately states an accelerated development strategy so called 13 future growth engines, in this case all these new industries and sectors are referred to a number of "breakthrough digital technologies" (smart cars, 5G networks, smart robotic engineering, smart portable devices etc.) Special Manufacturing Innovation 3.0 Strategy is being implemented in parallel; it lays emphasis on the internet of things, 3D-printing technologies and BigData technologies [19].

As for integration and international organizations, today the Organization for Economic Cooperation and Development (OECD) has adopted its Strategy for common digital market development. Special interstate treaties in the sphere of telecommunications and electronic commerce have been developed within the framework of Trans-Pacific Partnership (TPP). 
In 2015, ASEAN countries agreed a common Master-plan for the development of information and communication technologies [20].

\section{USA}

There is no common state program for the development of digital technologies in the United States of America; however, special technological initiatives were launched jointly with private business and scientific society in different years. As an example we can mention such programs as a federal initiative in the sphere of "cloud" computations (2009) or Barak Obama's initiative to create a new network of institutes-centers for advanced manufacturing ((AMP - Advanced Manufacturing Partnership, in 2011) involving the key federal departments and largest US high-tech companies. In addition, following an initiative of leading representatives of American private business (first of all - GE, AT\&T, IBM, Intel and Cisco) special Industrial Internet Consortium (IIC) was established in March 2014. Its main mission was declared to be "accelerated development, industrial implementation and wide distribution of interconnected machines, devices as well as intelligent analytics, in other words, industrial internet of things" [21].

\section{Eurasian Economic Union (EAEU)}

Russia also tries to keep pace with its competitors. Speaking about the creation of Russia's digital economy, one event should not go unnoticed, a meeting of the Counsel for strategic development and priority projects under the President of the Russian Federation, which discussed the planning and implementation of "RF digital economy" project. The aim of this project is to transform Russia's current economy, digitize it and improve its efficiency. This project involves large-scale changes in many key spheres of society's life, namely state and municipal administration, officialdom, education, management etc. The project frames precise objectives and tasks as wells as timelines.

The project makes provision for wide state support in five areas: regulatory control, human resources and education, development of research competence and technical capabilities, information infrastructure and information security -basis areas. The applicable areas include - state control, "smart city" and health care.

The program should result in countrywide connection of high-speed internet, implementation of $5 \mathrm{G}$ networks, enhancing the role of national servers and increasing their share up to $95 \%$, setting-up of new high-tech corporation, increasing the number of population with basic digital knowledge up to $50 \%$ and higher [22].

In 1997, in order to improve information support of research and technical sphere the Council of Ministers of the Republic of Belarus found it expedient to create a single research and information computer network in the republic [23]. From that moment the country started developing a Single research and information computer network of the Republic of Belarus (RICN), which includes networks of the Ministry of Educations, Belarus State University and scientific computer network of National Academy of Science of Belarus - BASNET. RICN incorporates a library network, a ground segment of Belarus's space remote probing system, a national grid-network, RINC provides off-line access to global computer networks through pan-European research and education network GEANT combining users from more than 8000 research and education organizations in 40 European countries. In 2016, the Government approved the State digital economy and information society development program for 2106-2020 [24]. The program includes nationwide subprograms, which contain backbone measures in the sphere of ICT development: information-communication infrastructure; information system development 
infrastructure; digital transformation. Herein the research results within the framework of the Program are subject to mandatory integration with the national automated information system (NAIS) in order to provide electronic services to citizens and legal entities. The Belarus high technology park (HTP) is the largest IT-cluster in Central and Eastern Europe. The most popular mobile application developed by this NTP is Viber, which is used by over $82 \mathrm{mln}$ people [27].

In Kazakhstan, by the President's decree in 2003 [26] a special economic zone was created (SEZ) "Innovative technologies park". Techno park "Alatau" was selected to be a service company within the territory of this SEZ, it also carries out activities as part of the implementation of state programs (technological business incubation of innovative projects, assistance in developing innovations and development of favorable conditions). The center of research laboratories including 4 laboratories was set up to stimulate the development of information and communication and digital technologies: laboratories of cloud technologies, laboratories of mobile technologies, laboratories of "Electronic government" architecture, Big Data laboratories. The state program "Digital Kazakhstan" was developed and approved for a period of 2017-2020, which includes four areas: digital Silk Road, creative society, digital transformation in economic sectors and proactive state. The key areas of the effective state program "Informational Kazakhstan-2020" are to make information and communication infrastructure accessible to population, develop telecommunication industry, create optical access networks in all large cities of the country, and provide the high-speed Internet to population.

The integration unions, in which the EAEU countries participate, also implement projects in the sphere of digital economy, which were initiated by state authorities, research societies and business. The Strategy for cooperation of CIS member states in building and developing information society for a period until 2025 and Implementation action plan were approved by a Resolution of the Council of the Heads of Governments the Commonwealth of Independent States dated October 28, 2016 [27]. This is already the second strategic document within the SIC framework in this area, the first one was approved in 2012. In 2016, in Saint Petersburg heads of the EAEU countries made a Statement on digital agenda of the Eurasian Economic Union, in which they declared to provide required conditions for forming "EAUE's digital agenda" [28].

\section{Conclusions}

Having analyzed the existing digital economy development concepts we can make a conclusion that there is no uniform plan of measures and actions, which can be used in all countries. State digital transformation support and stimulation programs are developed taking into account national features, capabilities of modern and future innovations being available here and there. At the same time they are aimed to leveling the fragmentation of markets, the standardization of data sources, which are obstacles on the way to digital transformation of global economy. The technological compatibility of architectures, standards, data, processes, platforms, infrastructures and networks at the interstate level making global integration possible has a crucial significance to the development and implementation of electronic ecosystem based on digital economy.

\section{References}

1. The World Economic Forum, Digital Transformation of Industries Demystifying Digital and Securing $\$ 100$ Trillion for Society and Industry by 2025 [online], Available at: $\quad$ http://reports.weforum.org/digital-transformation/wp- 
content/blogs.dir/94/mp/files/pages/files/wef-digital-transformation-2016-execsummary.pdf (2016)

2. European Commission, Coordination of European, national \& regional initiatives [online], Available at: https:/ec.europa.eu/digital-single-market/en/cordinationeuropean-national-regional-initiatives (2018)

3. Plattform-i40 [online], Available at: https://www.plattformi40.de/I40/Navigation/DE/Home/home.html (2018)

4. Smart networking [online], Available at: https://www.bmwi.de/Redaktion/EN/Dossier/ smart-networking.html (2018)

5. The Industry Technology Guide of the Future [online], Available at: http://www.industrie-dufutur.org/ (2018)

6. Department for Digital, Culture, Media \& Sport, UK Digital Strategy 2017 [online], Available at: https://www.gov.uk/government/publications/uk-digital-strategy/ukdigital-strategy (2017)

7. Smart Industry has the ambition that in 2021 the Netherlands will have the most flexible and the best digitally connected production network in Europe [online], Available at: https://www.smartindustry.nl/ (2018)

8. McKinsey Global Institute. Digital globalization: The new era of global flows [online], Available at: https://www.mckinsey.com/ /media/McKinsey/Business\%20Functions/ McKinsey\%20Digital/Our\%20Insights/Digital\%20globalization\%20The\%20new\%20e ra\%20of\%20global\%20flows/MGI-Digital-globalization-Full-report.ashx (2016)

9. G. Landheer, Digital revolution in industry. The Dutch approach [online], Available at: http://www.eesc.europa.eu/resources/docs/guido_landheer.pdf (2015)

10. Eurasian Economic Commission. Information and analytical report "An analysis of global experience in developing industrial sectors and approaches to digital transformation of industry in Eurasian Economic Union state members (2017)

11. C. Stolwijk, M. Punter, 101 ICT Developments in Smart Industry Field labs (TNO, Hague, 2017)

12. Smart Industry Field labs [online], Available at: https://www.smartindustry.nl/wpcontent/uploads/2018/02/SI-Fieldlabposter-A2-2018-NL-LR.pdf (2018)

13. Building the digital industrial Europe (2015) [online], Available at: http://europa.eu/rapid/press-release_SPEECH-15-5938_fr.htm (2015)

14. Digital Single Market - Digitizing European Industry [online], Available at: [http://europa.eu/rapid/press-release_MEMO-16-1409_en.htm (2016)

15. Ministry of Internal Affairs and Communications of Japan, Smart Japan ICT Strategy [online], Available at: http://www.soumu.go.jp/main_content/000301884.pdf (2014)

16. FICO At a Glance [online], Available at: http://www.fico.com/en/about-us\#at_glance (2018)

17. Tencent Announces 2017 Third Quarter Results [online], Available at: https://www.tencent.com/en-us/articles/15000651510741924.pdf (2017)

18. Alipay [online], Available at: https://intl.alipay.com/ (2018)

19. J. Kallio, Disruption Brief, 6 (2016)

20. Asean ICT masterplan 2015 completion report [online], Available at: http://www.asean.org/storage/images/2015/December/telmin/ASEAN\%20ICT\%20Co mpletion\%20Report.pdf (2015) 
21. The Industrial Internet Consortium [online], Available at: http://www.iiconsortium.org/ (2018)

22. Program "Digital economy of the Russian Federation" [online], Available at: [http://static.government.ru/media/files/9gFM4FHj4PsB79I5v7yLVuPgu4bvR7M0.pdf (2017)

23. Resolution of the Council of Ministers of the Republic of Belarus No.1677 (1997)

24. State Program for the development of digital economy and information society for 2016 - 2020" approved by Resolution of the Council of Ministers of the Republic of Belarus 23.03.2016 No 235) [online], Available at: http://www.government.by/upload/docs/file4c1542d87d1083b5.PDF (2016)

25. The number of Viber users in Russia has exceeded 82 million people [online], Available at: https://www.rbc.ru/rbcfreenews/58d0flab9a794704cbebceld (2017)

26. Decree of the President of the Republic of Kazakhstan dated August 18, 2003 No.1166 "On creation of special economic zone "Park of innovative technologies" (2003)

27. Digital agenda of the Eurasian Economic Union until 2025. Outlooks and recommendations [online], Available at: http://www.eurasiancommission.org/ru/act/d mi/SiteAssets/\%D0\%9E\%D0\%B1\%D0\%B7\%D0\%BE\%D1\%80\%20\%D0\%92\%D0\%9 1.pdf (2017)

28. Statement on digital agenda of the Eurasian Economic Union [online], Available at: [http://www.eurasiancommission.org/ru/act/dmi/workgroup/materials/Pages/docs.aspx (2018) 